\title{
Development of Integrated Technology of FRP Gear Manufacturing
}

Ihor Osadchiy ${ }^{1}$, Dmytro Kryvoruchko ${ }^{1}$, Vitalii Kolesnyk ${ }^{1}$, Michal Hatala $^{2}$, Jan Duplak ${ }^{2}$, Dusan Mital ${ }^{2}$

${ }^{1}$ Sumy State University, Department of Manufacturing Engineering, Machines and Tools, Rymskogo-Korsakova 2 st., 40007 Sumy, Ukraine.Email: osadchiy-igor@yandex.ru,dmytro.kryvoruchko@gmail.com, kol-vitaliy@ukr.net

${ }^{2}$ Technical University of Kosice, Faculty of Manufacturing Technologies, Bayerova 1, Presov 080 01, Slovakia. Email:

Gears are integral part of mechanisms and machines. The development of new composite materials impulse to increase of specific weight and load-carrying ability of gears. Current trend can be supplied with fiber reinforced materials (FRP) whose specific weight strength could by five times higher than of hardened steel. Those the mechanical properties of FRP wheel can substantially be influenced by technological heredity than metallic one. That is why the influence of technological steps should be taken into account during FRP wheels manufacture. The purpose of current research is to develop integrated technique of FRP wheels manufacture. Consequently in current experimental research the cooperation of load-carrying ability of non metallic and metallic wheels was provided. Different techniques were used for optimization of reinforcement fiber geometry when FRP wheels manufacture. Operating procedure of wheel manufacture contents computer simulation of forming, and properties programming helped to provide quality and load-carrying ability of the wheels.

Keywords: Machining; Polymer gear; Fiber orientation; CFRP; Gear metrology

\section{Acknowledgements}

The authors appreciate the financial support of Slovak Academic Information Agency in the framework of National Scholarship Program, Ministry of Education and Science of Ukraine in the framework of state grant № $0115 \mathrm{U} 000663$ and also, Airtech Company and Ecolan Ingredients LLC for raw material supply.

\section{References}

[1] HIROGAKI, T., AOYAMA, E., KATAYAMA, T., IWASAKI, S., YAGURA, Y., SUGIMURA, K. (2004). Design Systems for Gear Elements Made of Cotton Fiber-Reinforced Plastics. Composite Structures, 66, 47 - 52.

[2] STRYCZEK, J., BIERNACKI, K., KRAWCZYK, J., WOŁODŹKO, J. (2014). Application of Plastics in the Building of Fluid Power Elements. Вісник НТУУ «КПІ». Серія машинобудування, 2 (71), 5 - 11.

[3] KULISEK, V., JANOTA, M., RUZICKA, M., VRBA, P. (2013). Application of Fibre Composites in a Spindle Ram Design. Journal of Machine Engineering, 13(1), 7 - 23.

[4] WEALE, D., WHITE, J., WALTON, D. (1998). Effect of Fibre Orientation and Distribution on the Tooth Stiffness of a Polymer Composite Gear. Annual Technical Conference - ANTEC, Conference Proceedings, 3, 3008 - 3012.

[5] LEE, D., LEE, C., LEE, H., HWANG, H., KIM, J. (2004). Novel Applications of Composite Structures to Robots, Machine Tools and Automobiles. Composite Structures, 66, 17 - 39.

[6] BOTKO, F., HATALA, M., KORMOS, M., UNGUREANU, N., SOLTES, P. (2015). Using edgecam for creating CNC programs in educational process. In: SAMI 2015 - IEEE 13th International Symposium on Applied Machine Intelligence and Informatics, Proceeding. pp. 255-259. Publisher Institute of Electrical and Electronics Engineers Inc.

[7] HUTYROVA, Z., ZAJAC, J., FECOVA, V. (2014). Machining of non-homogeneous composite material with natural fibers reinforcement and HDPE matrix. In: Key engineering materials, Vol. 581, pp. 95 - 99. TTP. Switzerland.

[8] SLEGER, V., MIZERA, C. (2015). Comparison of the Continuous and Intermittent Relaxation Test. In: Manufacturing technology, Vol. 15, No. 2, pp. $210-214$

[9] STUSEK, J., MACAK, T. (2015). Design of Experiments for CNC Turning. In: Manufacturing technology, Vol. 15 , No. 3 , pp. $448-455$

[10] KOURIL K., CEP R., JANASEK A., KRIZ A., STANCEKOVA D. (2014). Surface Integrity at Reaming Operation by MT3 Head. In: Manufacturing technology, Vol. 14, No. 2, pp. 193 - 199 